\title{
Brimonidine-induced unilateral ocular lichen planus: a case report
}

\author{
Líquen plano ocular unilateral induzido por brimonidina: relato de caso \\ Nestor Ventura-Abreu', Maria Jesus Fernández-Aceñero², Carlos Narváez-Palazón', Angel Romo-López' \\ 1. Servicio de Oftalmología, Hospital Clínico San Carlos, Instituto de Investigación Sanitaria del Hospital Clínico San Carlos, Madrid, Spain. \\ 2. Servicio de Anatomía Patológica, Hospital Clínico San Carlos, Universidad Complutense de Madrid, Instituto de Investigación Sanitaria del Hospital \\ Clínico San Carlos, Madrid, Spain.
}

\begin{abstract}
I This report was written to describe a case of unilateral brimonidine-induced conjunctival lichen planus. Because the ophthalmic examination indicated chronic conjunctivitis or drug-induced pseudopemphigoid, the patient underwent thorough ophthalmic and systemic examinations, as well as conjunctival biopsy and direct immunofluorescence studies. A 71-year-old woman with unilateral left eye findings of chronic conjunctivitis was referred to our Ophthalmology Department. The patient reported that chronic conjunctivitis began shortly after she initiated use of topical brimonidine. Ophthalmic examination revealed foreshortening of the inferior fornix and symblepharon. Conjunctival biopsy revealed submucous lymphocytes and shaggy distribution of fibrinogen on direct immunofluorescence; this was suggestive of ocular lichen planus. No other systemic lesions were found that were consistent with the presentation of lichen planus. A good response was observed to topical cyclosporine treatment. To our knowledge, this may be the first report of unilateral ocular lichen planus without systemic findings. The correlation with the initiation of topical brimonidine suggests that this might be the first case of biopsy-confirmed brimonidine-induced ocular lichen planus.
\end{abstract}

Keywords: Brimonidine tartrate; Conjunctiva; Lichen planus; Cyclosporine

RESUMO I Este relato é para descrever um caso de líquen plano conjuntival unilateral induzido por brimonidina. Como o exame oftalmológico indicava conjuntivite crônica ou pseudopenfigóide induzido por medicamento, o paciente foi submetido a exames oftalmológicos e sistémicos completos,

Submitted for publication: June 12, 2018

Accepted for publication: November 24, 2018

Funding: No specific financial support was available for this study.

Disclosure of potential conflicts of interest: None of the authors have any potential conflicts of interest to disclose.

Corresponding autor: Nestor Ventura Abreu.

Hospital Clinico San Carlos. C/ Prof Martin Lagos, s/n, 28040, Madrid, Spain E-mail: ventanes@gmail.com além de biópsia conjuntival e estudos de imunofluorescência direta. Uma mulher de 71 anos de idade com achados unilaterais do olho esquerdo de conjuntivite crônica foi encaminhada ao nosso departamento de Oftalmologia. A paciente relatou que a conjuntivite crônica começou logo após o início do uso da brimonidina tópica. O exame oftalmológico revelou encurtamento do fórnice inferior e do symblepharon. A biópsia conjuntival revelou linfócitos submucosos e distribuição felpuda de fibrinogênio na imunofluorescência direta; isso era sugestivo de líquen plano ocular. Não foram encontradas outras lesões sistêmicas compatíveis com a apresentação do líquen plano. Uma boa resposta foi observada no tratamento tópico com ciclosporina. Pelo nosso conhecimento, este pode ser o primeiro relato de líquen plano ocular unilateral sem achados sistêmicos. A correlação com o início da brimonidina tópica sugere que este pode ser o primeiro caso de líquen plano ocular induzido por brimonidina confirmado por biópsia.

Descritores: Tartarato de brimonidina; Conjuntiva; Líquen plano; Ciclosporina

\section{INTRODUCTION}

Lichen planus (LP) is a well-recognized skin disease that is known to affect oral and genital mucosa. Ocular involvement of LP is uncommon, but should be suspected in patients with chronic conjunctivitis. In LP, isolated ocular involvement has been described without systemic involvement; however, in the previously reported cases, differential diagnosis with mucous membrane pemphigoid (MMP) was considered ${ }^{(1)}$. Although the precise mechanism remains unknown, autoimmunity and drug-related induction are two proposed mechanisms for $\mathrm{LP}^{(2)}$.

Brimonidine is a widely used antiglaucoma treatment that benefits glaucoma patients through two independent mechanisms: first, brimonidine provides a $20 \%-30 \%$ reduction of intraocular pressure (IOP); second, bri- 
monidine provides a potential neuroprotective effect independent of IOP. However, multiple systemic (e.g., dry mouth, headache, and increased risk of coronary insufficiency) and local side effects have been described. The exact incidences of these brimonidine-related side effects are unknown; however, there have been reports of as high as $32 \%$ of cases of blepharitis and blepharoconjuntivitis $^{(3)}$. Furthermore, use of brimonidine can trigger an allergic reaction to other glaucoma treatments and anterior uveitis ${ }^{(3)}$. LP, as we report in this case, may constitute a newly described local side effect.

\section{CASE REPORT}

A 71-year-old woman presented to the emergency room with the complaint of chronic aqueous discharge, itching, and red eye, all of which only affected the left eye. A fully detailed report summarizing her previous ocular history was provided by the patient. Notably, she had a history of angle-closure glaucoma in the left eye (OS), with subsequent cataract surgery; two penetrating keratoplasty procedures due to bullous keratopathy, both with corneal graft rejection; and in 2012, ocular hypertension in OS was detected, which led to initiation of antiglaucoma therapy with topical timolol.

Beginning in 2015, the patient was managed in both Glaucoma and Ocular Surface departments. Due to contraindications for use of prostaglandin and topical carbonic anhydrase inhibitor, as well as uncontrolled intraocular pressure, topical brimonidine was added in the left eye. However, the patient did not attend the scheduled medical visits and attempted self-medication through several cycles of topical antibiotics, topical steroids, and occasional use of artificial tears.

The patient finally presented to the emergency room in November 2017, reporting the onset of symptoms shortly after initiation of topical brimonidine. Visual acuity was light perception in the left eye, and ophthalmic examination showed blepharitis; swelling of the eyelid margin without clear signs of infection; chronic conjunctivitis with tarsal follicles; moderate hyperemia; nasal and temporal inferior symblepharon; no membranes or pseudomembranes; and corneal graft opacity with severe vascularization due to previous graft rejection (Figure 1).

Oral antibiotics were administered, along with topical steroids and lubrication with artificial tears and ointments. After 1 week of treatment, no changes were observed in the clinical appearance of the eyelids; furthermore, the conjunctiva continued to exhibit thickening and a redde- ned appearance. Magnetic resonance imaging ruled out orbital mass or malignancy, and indicated inflammatory disease involving the conjunctiva. Oral prednisone $0.5 \mathrm{mg} / \mathrm{kg} /$ day was initiated. A conjunctival biopsy was obtained from the inferior eyelid and serologic testing was performed for anti-basement membrane zone antibodies and anti-intercellular substance antibodies, due to initial suspicion of MMP. Histopathological examination revealed epithelium with inflammatory changes, as well as submucous lymphocytes with band-like distribution and foci of exocytosis. Based on these findings, a diagnosis of LP was suggested (Figure 2). Direct immunofluorescence examination revealed shaggy distribution of fibrinogen; moreover, anti-basement membrane zone antibodies and anti-intercellular substance antibodies were absent from the serum. A thorough general examination was performed, and no other skin or mucosal lesions were found. After diagnosis, treatment was adjusted, including tapering of oral steroids; topical cyclosporin $2 \%$ was initiated. Due to poor tolerance, treatment was modified; stabilization of symblepharon was achieved without any further eyelid malposition, as well as remission of the conjunctival hyperemia and symptoms, by using preservative-free topical dexamethasone t.i.d. and topical cyclosporine $1 \%$ b.i.d (Figure 3). No improvement in the graft was observed and visual acuity remained light perception.

\section{DISCUSSION}

LP is an inflammatory mucocutaneous disease, with an incidence of less than $1 \%(0.22 \%$ to $5 \%)$, affecting adults 30-60 years of age; however, cases have been reported in pediatric patients ${ }^{(4)}$. LP is a well-described entity, with classic presentation of purple, flat-polygonal papules with white striae on the surface; these typically affect the anterior regions of the wrist and ankles, as well as the lumbar region and internal surface of the tibia. LP involving mucous membranes is common; this typically affects oral mucosa, lips, and genitalia ${ }^{(5)}$.

Pathological findings have been defined previously. In patients with oral-mucosal LP, lymphocytes (specifically T-helper cells and cytotoxic T cells) infiltrate the basement membrane zone, accompanied by Langerhans cells and macrophages ${ }^{(2)}$. Similar findings have been described in biopsies of the conjunctiva in patients with ocular $\mathrm{LP}^{(5,6)}$. The presence of a coarse, shaggy distribution of fibrinogen at the basement membrane zone, detected by direct immunofluorescence, may also be helpful ${ }^{(5,7)}$. 


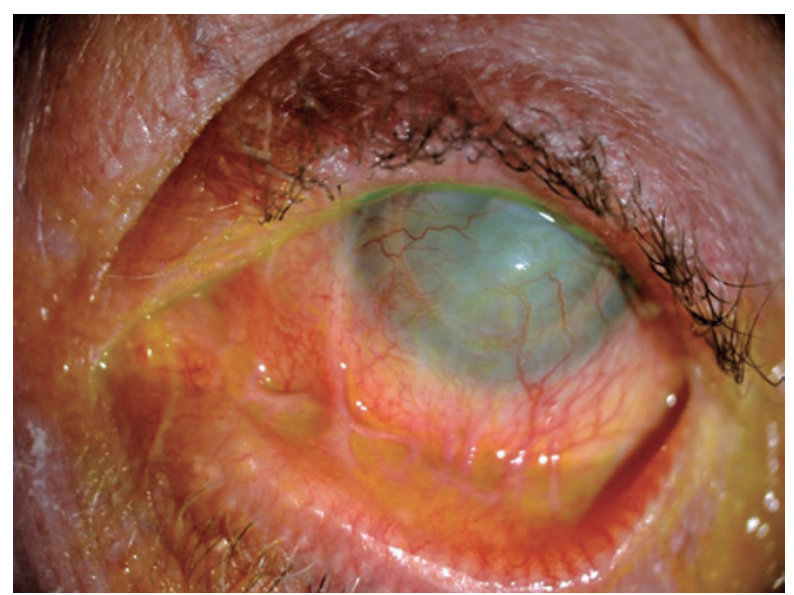

Figure 1. Slit-lamp examination of the patient at the time of presentation. Clearly marked symblepharon strands are visible in the inferior fornix; additionally, chronic, opaque vascularized corneal grafts are visible.

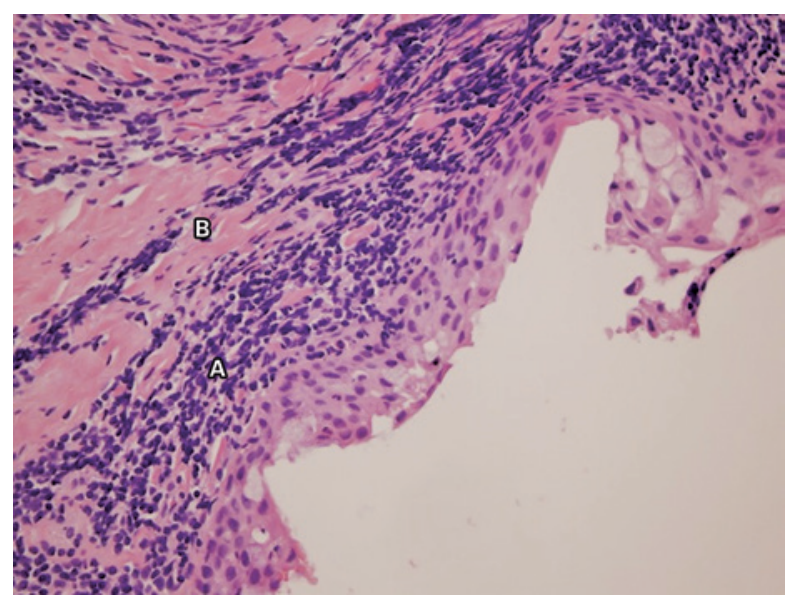

Figure 2. Hematoxylin-eosin staining of epithelium ('400). Submucous lymphocytes are present with band-like distribution (A) and shaggy fibrinogen (B) is evident in the basement membrane zone.

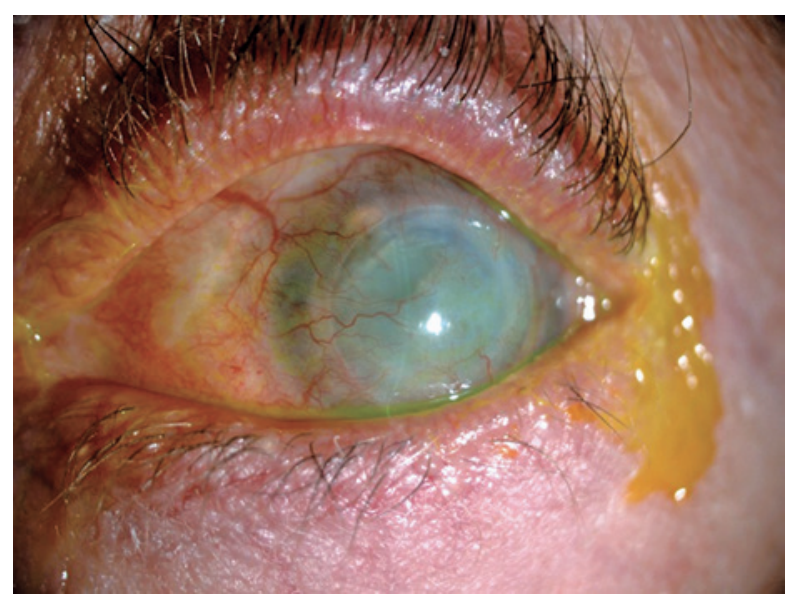

Figure 3. Slit-lamp examination of the patient after treatment. Improvement of conjunctival redness without further complications involving eyelid malposition due to symblepharon.
Cases of isolated ocular LP have been described previously. In most cases, bilateral presentation with symblepharon, foreshortening of the inferior or superior fornix, and ocular surface staining have been described; in such cases, the patients exhibited a good response to topical or systemic cyclosporine $e^{(4,5,7,8)}$.

Cases of drug-induced LP have been reported. Sodhi et al. described the case of a young female patient who developed LP in the little fingernail during topical brimonidine treatment, as confirmed by biopsy ${ }^{(9)}$. Upon cessation of topical brimonidine, changes in the nail retreated. In a large retrospective study, MMP and pseudopemphigoid/ possible MMP (PP/MMP) demographic and clinical characteristics were described. In the PP/MMP group, two separate groups were affected by topical antiglaucoma medications and LP, although lack of biopsy in the medication group could have led to misdiagnosis of $\mathrm{LP}^{(10)}$. In our patient, lack of LP in the skin, combined with unilateral administration of brimonidine and development of ocular LP in the same side, suggested that brimonidine was the underlying etiology. To our knowledge, this might be the first case report describing presumed brimonidine-induced ocular LP confirmed by biopsy. As reported here, patients who could not discontinue brimonidine may also benefit from topical cyclosporine treatment.

\section{REFERENCES}

1. Webster GF, Durrani K, Suchecki J. Ocular rosacea, psoriasis, and lichen planus. Clin Dermatol. 2018;34(2):146-50.

2. Neumann R, Dutt C), Foster CS. Immunohistopathologic features and therapy of conjunctival lichen planus. Am J Ophthalmol. 1993; 115(4):494-500.

3. Rahman MQ, Ramaesh K, Montgomery DM. Brimonidine for glaucoma. Expert Opin Drug Saf. 2010;9(3):483-91.

4. Igras E, Kennedy S, MacDermott EJ, Murphy CC. Isolated ocular lichen planus in a child. J AAPOS. 2015;19(4):381-3.

5. Rozas Muñoz E, Martínez-Escala ME, Juanpere N, Armentia J, Pujol RM, Herrero-González JE. Isolated conjunctival lichen planus: a diagnostic challenge. Arch Dermatol. 2011;147(4):465-7.

6. Ramos-Esteban JC, Schoenfield L, Singh AD. Conjunctival lichen planus simulating ocular surface squamous neoplasia. Cornea. 2009; 28(10):1181-3.

7. Mehta M, Siddique SS, Gonzalez-Gonzalez LA, Foster CS. Immunohistochemical differences between normal and chronically inflamed conjunctiva: diagnostic features. Am J Dermatopathol. 2011;33(8):786-9.

8. Thorne JE, Jabs DA, Nikolskaia OV, Mimouni D, Anhalt GJ, Nousari HC. Lichen planus and cicatrizing conjunctivitis: characterization of five cases. Am J Ophthalmol. 2003;136(2):239-43.

9. Sodhi PK, Verma L, Ratan J. Dermatological side effects of brimonidine: a report of three cases. J Dermatol. 2003;30(9):697-700.

10. Thorne JE, Anhalt GJ, Jabs DA. Mucous membrane pemphigoid and pseudopemphigoid. Ophthalmology. 2004;111(1):45-52. 